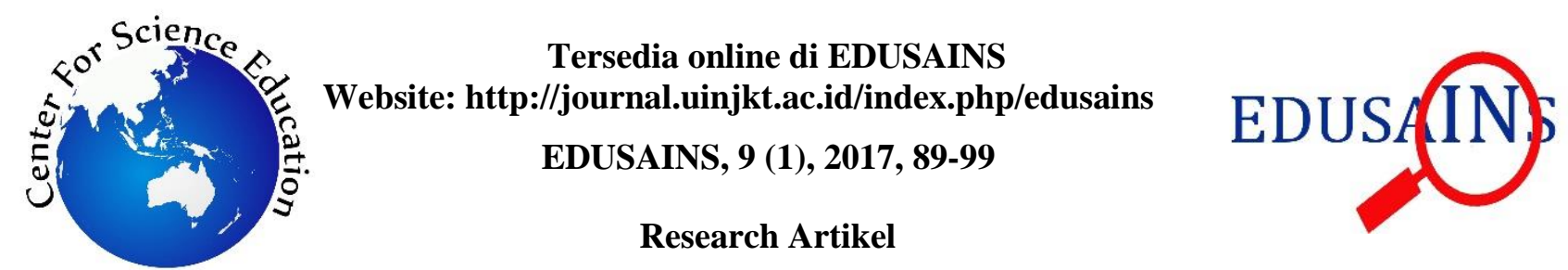

\title{
PENGUASAAN KONSEP MAHASISWA PADA MATA KULIAH ZOOLOGI VERTEBRATA MELALUI TEAM-BASED LEARNING DAN HUBUNGANNYA DENGAN KETERAMPILAN BERPIKIR KRITIS
}

\author{
Sumiyati Sa'adah $^{1}$, Fransisca Sudargo ${ }^{2}$, Topik Hidayat ${ }^{3}$ \\ ${ }^{1}$ Pendidikan Biologi Fakultas Tarbiyah dan Keguruan UIN SGD Bandung, Indonesia \\ ${ }^{2,3}$ Pascasarjana Universitas Pendidikan Indonesia (UPI), Bandung, Indonesia \\ sumiyatisaadah@uinsgd.ac.id
}

\begin{abstract}
This study aims to analyze the improvement of mastery of student concepts after the implementation of team-based learning strategy, as well as to analyze its relationship with critical thinking skills. The research method is a quasi-experiment with pretest-posttest control group design. The subject of this study consists of 40 students who attended vertebrate zoology courses as an experimental class and 45 students as control class. The instrument used is the multiple choice test. The data obtained were analyzed statistically using SPSS 16 comprising analysis of mean difference test (t-test), effect size, and Pearson two tail correlation test. The result shows that the improvement of student mastery concept in experimental class is better than control class. This can be seen from the average difference test (t-test) of $\mathrm{N}$-gain $(<\mathrm{g}>)$ which shows a significant difference $(\alpha=5 \%)$, and the value of effect size (d) of 0.68 (high category). The Result of correlation test shows that critical thinking skill has a positive relation with mastery of student concept with co-determination value 0.4058 which means that critical thinking skill contributes $40.58 \%$ to student mastery concept.
\end{abstract}

Keywords: team-based learning, concept mastery, zoology vertebrate courses

\begin{abstract}
Abstrak
Penelitian ini bertujuan untuk menganalisis peningkatan penguasaan konsep mahasiswa setelah diterapkannya pembelajaran berbasis kelompok, serta menganalisis hubungannya dengan keterampilan berpkir kritis. Metode penelitian yang dilakukan adalah quasi experiment dengan disain penelitian pretest - postest control group design. Sampel penelitian terdiri atas 40 orang mahasiswa yang mengikuti kuliah zoologi vertebrata sebagai kelas eksperimen dan 45 orang mahasiswa sebagai kelas kontrol. Instrumen yang digunakan adalah tes penguasaan konsep. Data yang diperoleh dianalisis statistik menggunakan SPSS 16 meliputi analisis uji beda rerata (uji t), effect size, dan uji korelasi Pearson two tail. Hasil penelitian menunjukkan bahwa peningkatan penguasaan konsep mahasiswa pada kelas ekpserimen lebih baik dibandingkan kelas kontrol. Hal ini dapat dilihat dari uji beda rerata (uji t) $\mathrm{N}$-gain $(\langle\mathrm{g}\rangle$ ) yang menunjukkan beda signifikan $(\alpha=5 \%)$, dan nilai efect size (d) sebesar 0.68 (kategori tinggi). Hasil uji korelasi menunjukkan bahwa keterampilan berpikir kritis memiliki hubungan positif dengan penguasaan konsep mahasiswa dengan nilai koofesien determinasi sebesar 0.4058 yang berarti bahwa keterampilan berpikir kritis memberikan kontribusi sebesar $40.58 \%$ terhadap penguasaan konsep mahasiswa.
\end{abstract}

Kata Kunci: team-based learning, penguasaan konsep, zoologi vertebrata

Permalink/DOI: http://dx.doi.org/10.15408/es.v9i1.5475

\section{PENDAHULUAN}

Sains atau Ilmu Pengetahuan Alam dibutuhkan manusia untuk membantu kehidupan sehari-hari. Sains merupakan kumpulan pengetahuan tentang fenomena alam dan proses yang diperoleh dari hasil pemikiran dan penelitian ilmuwan (Sund dan Trowbribge, 1973; Hungerford dan Ramsey, 1990). Rutherford \& Ahlgren (1990) mengungkapkan bahwa sains merupakan proses, produk, dan pengembangan sikap, dengan demikian pendidikan sains merupakan usaha para pendidik untuk menyampaikan proses dan produk hasil penelitian ilmuan dan mengembangkan sikap peserta didiknya. Tujuan pendidikan sains adalah 
untuk mengembangkan literasi sains (Milne, 2004; Rutherford \& Ahlgren, 1990); mempelajari prinsipprinsip dan konsep-konsep sains yang penting (learning science/belajar sains), mengembangkan keterampilan prosedural dan keterampilan penalaran kritis yang diperlukan dalam melakukan penyelidikan ilmiah (learn to do sciencel belajar untuk melakukan sains), memahami sifat sains sebagai aktivitas manusia dan cara membangun pengetahuan (learn about sciencel belajar tentang sains) (NRC, 1996). Salah satu tujuan pendidikan sains adalah untuk mengembangkan keterampilan berpikir kritis (Bailin, 2002), yang berarti menghindari menghafal istilah, tetapi membangun hubungan antarkonsep, menerapkan kerangka kerja yang tepat untuk pemecahan masalah, dan menarik kesimpulan secara kritis (Bransford et al, 2000). Hal ini berarti bahwa pendidikan sains menekankan bagaimana caranya agar mahasiswa memahami, mendapatkan, mengaplikasikan dan menguasai konsep bukan hanya menghafalkannya serta menggunakan konsep sebagai landasan untuk berfikir (Dahar, 2011). Pendidikan sains dapat membantu mahasiswa mengembangkan pemahaman dan kebiasaan berfikir, sehingga mahasiswa mempunyai kemampuan untuk menjamin kelangsungan hidupnya (Rutherford \& Ahlgren, 1990). Untuk mencapai tujuan tersebut mahasiswa harus terlibat aktif dalam proses pembelajaran di dalam kelas, Salah satu strategi pembelajaran aktif adalah strategi pembelajaran berbasis kelompok atau team-based learning (Michaelsen \& Sweet, 2008b).

Pembelajaran berbasis kelompok atau teambased learning (TBL) merupakan sebuah strategi pedagogi yang berlandaskan pada kerjasama sekelompok mahasiswa untuk mempelajari suatu materi pembelajaran. Tujuan utama dari proses belajar dengan pembelajaran berbasis kelompok ini adalah memberikan kesempatan kepada mahasiswa untuk berlatih konsep-konsep selama belajar di kelas dan berlatih menerapkan konsep dalam memecahkan masalah (Clair \& Cihara, 2012; Michaelsen \& Sweet, 2008a). Strategi ini terdiri atas tiga tahapan (Michaelsen \& Sweet, 2008a), yaitu:

(1) Tahap pertama adalah tugas membaca sebelum mahasiswa mengikuti pembelajaran di kelas. Fase ini dilakukan di luar kelas dengan cara mahasiswa belajar mandiri.

(2) Tahap kedua adalah tes individual (IRAT/individual readiness assurance test) dengan memberikan tes pilihan berganda, dilanjutkan dengan tes kelompok (group readiness assurance test/GRAT) dengan mengerjakan tes yang sama dengan tes individual tetapi dikerjakan secara berkelompok. Pada tahap ini pengajar pemberian umpan balik dan penjelasan singkat terkait konsepkonsep yang belum jelas

(3) Tahap ketiga adalah tahap aplikasi atau latihan konsep dengan menyelesaikan tugas baru secara berkelompok

Lamm et al (2014) menyatakan bahwa pembelajaran berbasis kelompok dapat meningkatkan kualitas belajar mahasiswa dengan mendorong keterampilan bekerja sama tanpa mengorbankan mahasiswa untuk memperoleh konsep dalam disiplin ilmu. Lebih jauh Lamm et al (2014) menyatakan bahwa strategi pembelajaran berbasis kelompok membutuhkan keterlibatan yang tinggi dari mahasiswa dan dapat digunakan untuk melatih keterampilan berpikir kritis. Wiegant et al (2012) menyatakan bahwa strategi pembelajaran berbasis kelompok efektif untuk digunakan dalam mengajar mahasiswa karena dapat mengembangan keterampilan mahasiswa, melatih kepercayaan diri, memberikan motivasi pada mahasiswa untuk melakukan yang lebih baik dari apa yang sudah mereka miliki.

Strategi TBL memberikan banyak manfaat bagi mahasiswa. Jika TBL diterapkan dengan baik, mahasiswa memperoleh pengetahuan dan mendapatkan pemahaman yang mendalam karena sepanjang pembelajaran mahasiswa diberikan serangkaian permasalahan yang kompleks, yang setiap mahasiswa berusaha untuk memecahkannya, baik individual maupun secara berkelompok (Michaelsen \& Sweet, 2008a). Selain itu, mahasiswa juga dilatih untuk menghargai dan bekerjasama dalam sebuah tim. TBL juga melatih berbagai keterampilan seperti keterampilan berkomunikasi, keterampilan memberi dan menerima umpan balik dari teman sebaya, keterampilan memecahkan masalah, keterampilan berpikir tinggi termasuk keterampilan berpikir 
kritis, melatih kemandirian belajar dan tanggung jawab serta mengembangkan keterampilan bagi siswa untuk menjadi pembelajar seumur hidup (Michaelsen \& Sweet, 2008b; Jensen et al, 2008; Lettasy et al, 2008; Lamm, 2014). Strategi pembelajaran TBL mengikuti prinsip-prinsip teori konstruktivisme. Hal ini dapat dilihat dari peran pengajar yang bertindak sebagai fasilitator dalam belajar. Selain itu, TBL merupakan strategi pembelajaran aktif yang berpusat pada mahasiswa dan hal ini sesuai dengan prinsip teori belajar konstruktivisme (Hrynchak \& Battty, 2012). Strategi TBL juga dilandasi oleh teori konstruksi sosial Vigostky. Menurut Vigotsky (Blake \& Pope, 2008) bahwa interaksi sosial memainkan peran penting dalam proses belajar peserta didik, melalui interaksi sosial peserta didik belajar satu sama lain dan strategi TBL memfasilitasi hal tersebut.

\section{METODE}

Metode yang digunakan dalam penelitian ini adalah quasi experiment dengan disain penelitian Pretest - Postest Control Group Design. Satu kelas sebagai kelas eksperimen yaitu kelas yang menggunakan strategi pembelajaran berbasis kelompok (TBL) dan kelas lainnya sebagai kelas kontrol mengunakan diskusi, ceramah dan tanya jawab. Kelas eksperimen berjumlah 40 orang mahasiswa dan kelas kontrol berjumlah 45 orang mahasiswa. Penelitian ini dilaksanakan di UIN SGD Bandung, pada mahasiswa semester 4 yang mengikuti mata kuliah zoologi vertebrata. Penelitian ini dilakukan sebanyak 10 kali pertemuan, dengan materi yang disajikan adalah Osteichthyes, Amphibia, Reptilia, Aves, dan Mamalia. Instrumen yang digunakan untuk mengukur pengusaan konsep adalah instrumen tes yang terdiri atas 20 pertanyaan pilihan berganda yang sebelumnya telah diujicobakan dengan nilai reliabilitas sebesar 0.73 (kategori tinggi). Data yang diperoleh dihitung dengan menggunakan SPSS 16 dengan taraf signifikansi 5\% yang meliputi uji beda rerata (uji t), effect size, dan uji korelasional Pearson two tail. Instrumen lain yang digunakan adalah instrumen untuk mengukur keterampilan berpikir kritis yang berupa soal uraian sebanyak 15 soal yang setiap soal disesuaikan dengan indikator berpikir kritis Noris-Ennis.

Implementasi TBL dalam pembelajaran di kelas diawali dengan pemberian tes individu, mahasiswa sebelumnya diberikan hand out dan diminta untuk mempelajari materi yang akan dibahas di kelas. Setelah tes individu selesai, mahasiswa duduk dalam kelompok yang sebelumnya telah ditetapkan, dan mengerjakan soal yang sama dengan tes individu tetapi secara berkelompok. Pada tahapan ini mahasiswa mendiskusikan soal-soal dan menetapkan jawaban bersama. Setelah selesai berdiskusi mahasiswa bersama pengajar membahas soal-soal dan pengajar menjelaskan secara singkat hal-hal yang belum jelas. Tahap terakhir mahasiswa melatih dan mengaplikasikan konsep dengan membahas soalsoal yang baru secara berkelompok di bawah arahan pengajar dan diikuti pembahasan secara bersama-sama.

\section{HASIL DAN PEMBAHASAN}

Setelah dilakukan pengukuran penguasaan konsep dengan instrumen es pilihan berganda, maka rata-rata nilai tes awal, tes akhir, $N$-gain $(<\mathrm{g}\rangle)$ mahasiswa pada kelas kontrol (yang tidak menggunakan TBL) dan eksperimen (yang menggunakan TBL) dapat dilihat pada Gambar 1.

Gambar 1 dapat diketahui bahwa setelah dilakukan pembelajaran, terjadi peningkatan penguasaan konsep mahasiswa baik pada kelas kontrol maupun kelas eksperimen. Berdasarkan data $N$-gain ( $<\mathrm{g}\rangle$ ) pada Gambar 1 . di atas, terlihat bahwa peningkatan penguasaan konsep mahasiswa pada kelas kontrol maupun kelas eksperimen berada pada kategori sedang (Hake, 1998), namun walaupu demikian nilai $N$-gain $(\langle\mathrm{g}\rangle)$ kelas eksperimen lebih tinggi.

Sebaran peningkatan penguasaan konsep (nilai $\langle\mathrm{g}\rangle$ ) setiap mahasiswa yang masuk ke dalam kategori tinggi, sedang dan rendah baik pada kelas kontrol dan kelas eksperimen, dilakukan penghitungan $\mathrm{N}$-gain setiap mahasiswa dan hasilnya disajikan pada Gambar 2. 


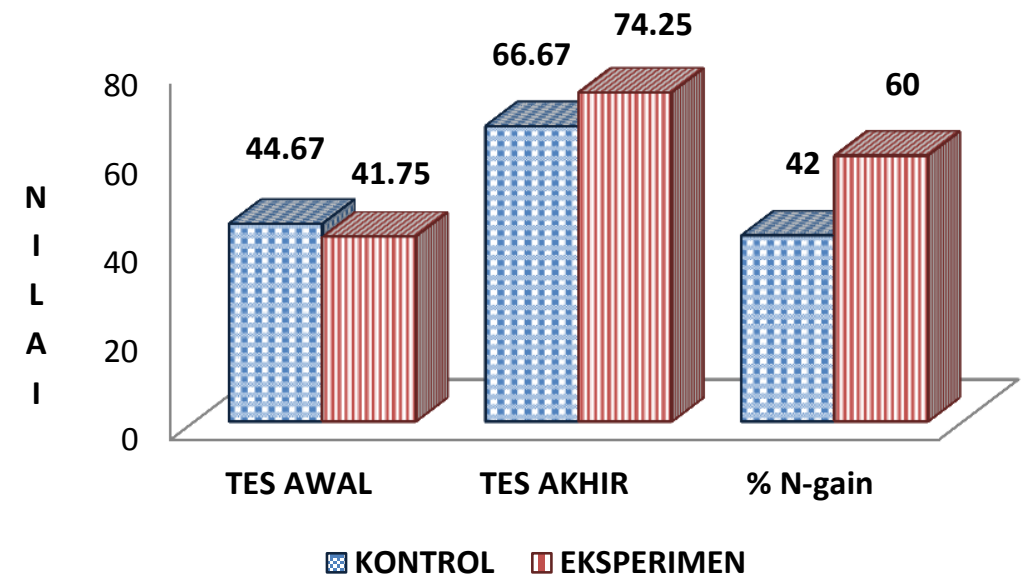

Keterangan: jumlah mahasiswa $(\mathrm{N})$ kelas kontrol = 45, N kelas eksperimen 40

Gambar 1. Rata-rata nilai tes awal, tes akhir, $N$-gain penguasaan konsep mahasiswa kelas kontrol dan kelas eksperimen pada materi zoologi vertebrata
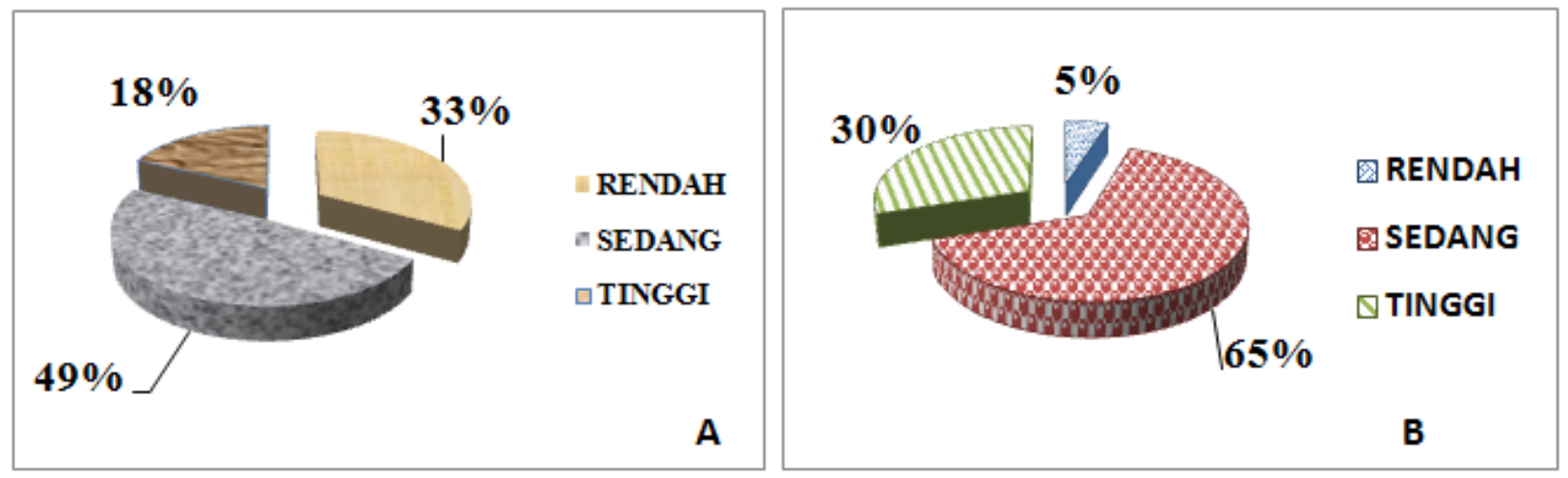

Keterangan: $\mathrm{n}$ untuk kelas kontrol $=45, \mathrm{n}$ kelas eksperimen $=40$

Gambar 2. Rekapitulasi persentase kategori n-gain $(<\mathrm{g}\rangle)$ penguasaan konsep mahasiswa pada kelas kontrol (a) dan kelas eksperimen (B)

Gambar 2 memberikan informasi bahwa persentase $\mathrm{N}$-gain $(<\mathrm{g}\rangle)$ mahasiswa kelas kontrol dan kelas eksperimen yang terbanyak terdapat pada kategori sedang, dengan persentase yang berbeda. Diagram pada Gambar 2 juga menunjukkan bahwa persentase nilai $N$-gain $(<\mathrm{g}>)$ untuk kategori tinggi pada kelas eksperimen, lebih banyak dibandingkan dengan kelas kontrol dan persentase nilai $\mathrm{N}$-gain untuk kategori rendah lebih sedikit dibandingkan kelas kontrol.
Kebermaknaan peningkatan penguasaan konsep mahasiswa, dilakukan pengujian statistik menggunakan SPSS versi 16 terhadap nilai tes awal, tes akhir, dan $\quad N$-gain $(\langle\mathrm{g}\rangle)$ baik pada kelas kontrol maupun pada kelas eksperimen. Pengujian Statistik meliputi uji normalitas dengan menggunakan Kolmogorov-Smirnov (K-S), uji homogenitas varians menggunakan Levene Test, uji dua beda rerata menggunakan uji t, dan effect size (d). Rekapitulasi hasil pengujian statistik disajikan pada Tabel 1.

Tabel 1. Perhitungan Statistik Uuntuk Nilai Tes Awal, Tes Akhir, dan N-Gain Penguasaan Konsep Mahasiswa pada Kelas Kontrol dan Kelas Eksperimen

\begin{tabular}{|c|c|c|c|c|c|}
\hline & \multicolumn{2}{|c|}{ Uji Normalitas $(\alpha=0.05)$} & \multirow{2}{*}{$\begin{array}{l}\text { Homogenitas } \\
\qquad(\alpha=\mathbf{0 . 0 5})\end{array}$} & \multicolumn{2}{|c|}{ Uji t $(\alpha=0.05)$} \\
\hline & $\begin{array}{c}\text { Kelas } \\
\text { Eksperimen }\end{array}$ & $\begin{array}{c}\text { Kelas } \\
\text { Kontrol }\end{array}$ & & Sig. & Makna \\
\hline Tes Awal & $\begin{array}{c}\text { Sig. } 0.347 \\
\text { (normal) }\end{array}$ & $\begin{array}{l}\text { Sig. } 0.779 \\
\text { (normal) }\end{array}$ & $\begin{array}{l}\text { Sig. } 0.003 \text { (tidak } \\
\text { homogen) }\end{array}$ & 0.808 & Tidak Signifikan \\
\hline $\mathrm{N}$-gain & $\begin{array}{l}\text { Sig. } 0.566 \\
\text { (normal) }\end{array}$ & $\begin{array}{c}\text { Sig. } 0.159 \\
\text { (normal) } \\
\text { Effect Size }(\mathrm{d})=0.68\end{array}$ & $\begin{array}{l}\text { Sig. } 0.055 \text { (tidak } \\
\text { homogen) }\end{array}$ & 0.008 & $\begin{array}{c}\text { Signifikan } \\
\text { Tinggi }\end{array}$ \\
\hline
\end{tabular}


Tabel 2. Perolehan Nilai Tes Awal, Tes Akhir, N-Gain Kelas Kontrol dan Kelas Eksperimen pada Setiap Submateri Bahasan

\begin{tabular}{ccccccccc}
\hline \multirow{2}{*}{$\begin{array}{c}\text { Indikator } \\
\text { Materi }\end{array}$} & \multicolumn{3}{c}{ Kes } & Tes & \multicolumn{3}{c}{ Kelas Eksperimen } \\
\cline { 2 - 9 } & Awal & Akhir & <g & \multirow{2}{*}{ Kategori } & $\begin{array}{c}\text { Tes } \\
\text { Awal }\end{array}$ & $\begin{array}{c}\text { Tes } \\
\text { Akhir }\end{array}$ & $\langle$ g $\rangle$ & \multirow{2}{*}{ Kategori } \\
\hline Mamalia & 24.44 & 59.44 & 0.46 & Sedang & 24.40 & 55.03 & 0.47 & Sedang \\
Aves & 53.89 & 70.00 & 0.35 & Sedang & 57.65 & 80.63 & 0.54 & Sedang \\
Reptilia & 60.00 & 72.22 & 0.31 & Sedang & 56.88 & 77.50 & 0.49 & Sedang \\
Amphibia & 48.33 & 58.89 & 0.20 & Rendah & 34.88 & 68.13 & 0.52 & Sedang \\
Osteichthyes & 36.67 & 53.89 & 0.27 & Rendah & 34.75 & 83.75 & 0.76 & Tinggi \\
\hline
\end{tabular}

Tabel 1 menunjukkan bahwa hasil analisis uji beda rerata untuk tes awal pada kedua kelas tidak berbeda secara signifikan. Hal ini berbeda dengan hasil uji beda rerata untuk $N$-gain $(\langle\mathrm{g}\rangle)$ yang menunjukkan beda secara signifikan. Hal ini dapat disimpulan bahwa kelas eksperimen secara signifikan dapat meningkatkan penguasaan konsep mahasiswa. Jika dilihat dari nilai Effect Size (0.68), dampak strategi RF-TBL dalam meningkatkan penguasaan konsep mahasiswa ada dalam kategori tinggi.

Perbandingan rata-rata nilai $N$-gain $(\langle\mathrm{g}\rangle)$ untuk setiap submateri bahasan zoologi vertebata yang disajikan selama pembelajaran antara kelas kontrol dan kelas eksperimen dapat dilihat pada Tabel 2. Berdasarkan Tabel 2 dapat dilihat bahwa untuk kelas eksperimen submateri zoologi vertebrata yang menghasilkan nilai $\mathrm{N}$-gain dengan kategori tinggi adalah submateri Osteichthyes, tetapi kategori rendah untuk kelas kontrol.

Hasil penelitian implementasi pembelajaran berbasis kelompok (TBL) dalam meningkatkan penguasaan konsep mahasiswa dapat tercapai dengan baik, sebagaimana yang ditunjukkan pada Gambar 1. Hasil uji statistik pada Tabel 1 menunjukkan bahwa pada nilai tes awal kelas kontrol dengan kelas eksperrimen tidak menunjukkan adanya perbedaan, hal ini berarti kemampuan awal mahasiswa di kelas eksperimen dan di kelas kontrol tidaklah berbeda. Berbeda halnya dengan nilai $N$-gain $(<\mathrm{g}>)$ yang menunjukkan perbedaan signifikan antara kelas eksperimen dan kelas kontrol. Hal ini berarti, peningkatan penguasaan konsep mahasiswa pada kelas eksperimen lebih baik dibandingkan kelas kontrol.

Perbedaan rerata $N$-gain $(<\mathrm{g}\rangle)$ yang signifikan antara kelas eksperimen dengan kelas kontrol tidak terlepas dari diimplentasikannya strategi pembelajaran berbais kelompok (TBL) dalam perkuliahan zoologi vertebrata. Hal ini pun dibuktikan dari nilai effect size-nya yaitu sebesar 0.68 yang masuk kategori tinggi (Cohen, 1988), yang berarti bahwa pengaruh strategi pembelajaran berbasis kelompok tidak bisa diabaikan dalam meningkatkan penguasaan konsep mahasiswa, karena menurut Leech et al (2005) hanya yang nilai effect size-nya kecil yang bisa diabaikan atau tidak penting pengaruhnya.

Implementasi strategi pembelajaran berbasis kelompok yang dapat meningkatkan penguasaan konsep mahasiswa disebabkan strategi ini menekankan pada kegiatan mahasiswa dalam kelompok-kelompok kecil. Selain itu, tahap-tahap TBL memberikan ruang bagi mahasiswa untuk memperdalam konsep yang dipelajari. Hal ini karena selama implementasi TBL, mahasiswa aktif berdiskusi dengan teman sekelompok untuk menjawab soal-soal yang diberikan. Mereka harus mencapai kesepakatan dalam menetapkan jawaban kelompok. Berdasarkan hasil obeservasi selama pembelajaran berlangsung, sebagian besar mahasiswa terlibat dalam memecahkan soal yang diberikan baik dalam tahap Grat maupun dalam tahap aplikasi konsep. Hal ini dibuktikan dengan skor kerja kelompok selalu lebih besar dibandingkan skor individual. Menurut Fink (2008) pembelajaran melalui kelompok-kelompok kecil dapat membantu mahasiswa dalam memahami materi dan memberikan kesempatan untuk belajar menerapkan materi tersebut. Lebih jauh Fink (2008) mengemukakan bahwa dengan bekerja bersama kelompok memberikan peluang kepada mahasiswa untuk memahami isi materi, karena bekerja bersama kelompok menuntut mereka untuk menggunakan pengetahuan yang mereka miliki dalam memecahkan masalah. Ketika belajar dalam kelompok, mahasiswa terlibat pada tugas atau masalah dan secara aktif berinteraksi dengan konten yang sedang dibahas, mahasiswa diberikan peluang yang sangat terbuka untuk 
mengembangkan alternatif jawaban, berbagi informasi dengan kelompoknya dan menetapkan jawaban yang benar. Dengan cara belajar seperti ini dapat mempengaruhi hasil kinerja belajar mereka (Ofstad \& Brunner, 2013). Lee (2014) melaporkan bahwa keterlibatan mahasiswa di kelas menjadi prediktor signifikan dari kinerja akademik. Marks (2000) menemukan bahwa mahasiswa lebih terlibat dalam pembelajaran ketika mereka terlibat dalam pembelajaran yang bermakna seperti, menggali secara mendalam suatu topik, diskusi bersama mahasiswa yang lain, menerapkan konsep untuk masalah kehidupan di luar kelas. Menurut Livingston et al (2014) semakin mahasiswa terlibat dalam proses pembelajaran, semakin tinggi tingkat retensi terhadap materi maka akan mencapai ketuntasan dalam belajar.

Parappilly (2015) mengungkapkan bahwa TBL berhasil membangun lingkungan belajar yang diinginkan, mendorong keterlibatan mahasiswa untuk berpartisipasi aktif sehingga mengurangi tingkat kegagalan. Lebih jauh Parapily (2015) melaporkan bahwa TBL memiliki dampak positif bagi cara belajar mahasiswa, hal ini dimungkinkan karena setiap mahasiswa bertanggung jawab untuk mempersiapkan materi pelajaran sebelum dilakukan tes. Tahapan pertama TBL adalah tahap persiapan awal yang dilakukan sebelum mahasiswa masuk ke dalam kelas dengan meminta mahasiswa untuk membaca materi yang akan dipelajari (tugas membaca), disertai membuat resume materi sebagai persiapan untuk menghadapi tes. Nieder (2005) mengemukakan bahwa TBL dapat membantu mahasiswa memahami konsep-konsep dan membantu mereka belajar secara konsisten. Mahasiswa harus terus berinteraksi dengan materi kuliah setiap hari karena dituntut untuk tes setiap pertemuan. Hal ini berbeda dengan kebisaan mahasiswa sebelumnya, yaitu mereka baru belajar atau membaca materi perkuliahan di minggu terakhir sebelum ujian akhir dilaksanakan. Pemberian umpan balik yang secara langsung baik oleh pengajar atau sesama teman dalam TBL pemberikan dampak positif pada hasil belajar mahasiswa. Hal ini memungkinkan karena pemberian umpan balik dapat mengidentifikasi kesenjangan pengetahuan, mengatasi kesalahan atau kekurangan dalam pembelajaran atau penguasaan materi dan dengan demikian mendorong kemampuan untuk self-assessment.

Berbagai penelitian menunjukkan bahwa implementasi TBL dapat membantu mahasiswa untuk menguasai konsep yang dipelajari. Penelitian Behling et al (2016) yang menunjukkan bahwa strategi TBL efektif meningkatkan pemahaman mahasiswa tentang isi perkuliahan mikrobiologi yang diukur dengan nilai postetst, atau dengan kata lain lain strategi TBL dapat meningkatkan hasil belajar mahasiswa di perkuliahan mikrobiologi. Penelitian Rezaee (2015) melaporkan bahwa implementasi TBL meningkatkan performa akademik mahasiswa yang ditandai dengan skor akademik yang meningkat. Penelitian Huit et al (2014) melaporkan bahwa TBL merupakan suplemen efektif untuk diseksi kadaver di laboratorium anatomi, sehingga dapat meningkatkan nilai para mahasiswa dan persepsi mahasiswa terhadap kerja sama tim. Penelitian Chung (2009) menunjukkan salah satu manfaat utama dari TBL adalah bahwa kinerja akademis mahasiswa yang lemah meningkat dibandingkan dengan prestasi mereka dalam perkuliahan lainnya yang diajarkan menggunakan ceramah tradisional.

Data peningkatan setiap indikator penguasaan konsep seperti yang diperlihatkan dalam Tabel 2 menunjukkan bahwa pada kelas eksperimen materi Osteichthyes (ikan bertulang sejati) merupakan materi yang nilai $\mathrm{N}$-gain $(<\mathrm{g}\rangle)$-nya termasuk ke dalam kategori tinggi, sedangkan materi-mataeri lainnya nilai $N$ gainnya $(<\mathrm{g}\rangle)$ termasuk ke dalam kategori sedang. Sedangkan pada kelas kontrol nilai $N$-gain $(<\mathrm{g}\rangle)$ untuk materi Osteichthyes pada kategori rendah juga untuk Reptilia, materi yang lainnya nilai $N$ gainnya $(\langle\mathrm{g}\rangle)$ berada pada kategori sedang. Nilai $N$-gain $(<\mathrm{g}\rangle)$ yang masuk kategori tingi di kelas eksperimen pada materi Osteichthyes diduga karena mahasiswa lebih familiar (mengenal) anggota kelompok ikan bertulang sejati dibandingkan dengan kelas yang lain. Kelompok ikan bertulang sejati memiliki jumlah species terbanyak dibandingkan dengan kelas lain (Hickman et al, 2001), dan banyak dari anggota kelompok ini yang dekat dengan kehidupan sehari-hari mahasiswa seperti digunakan sebagai bahan makanan, hiasan di akuarium, kegiatan wisata memancing, dll. 
Sebaran nilai tes awal, tes akhir dan $N$-gain $(<\mathrm{g}\rangle)$ keterampilan berpikir kritis untuk kelas yang mengunakan pembelajaran berbasis kelompok (TBL) yang diurutkan berdasarkan urutan nilai $N$-gain $(\langle\mathrm{g}\rangle)$ dari yang terendah sampai tertinggi dapat dilihat pada Gambar 3.

Gambar 3 memberikan informasi bahwa, mahasiswa mengalami peningkatan keterampilan berpikir kritis setelah diimplementasikannya strategi pembelajaran TBL. Untuk mengetahui bagaimana hubungan antara keterampilan berpikir kritis dengan penguasaan konsep mahasiswa setelah menggunakan strategi pembelajaran TBL apakah bersifat positif atau negatif dilakukan penghitungan uji korelasi terhadap nilai keterampilan berpikir kritis dan penguasaan konsep mahasiswa. Penghitungan uji korelasi menggunakan Pearson two tailed sampel berpasangan, pada taraf signifikansi 0.01 . Rekapitulasi hasil perhitungan koefisien korelasinya disajikan pada Tabel 3.
Tabel 3 memberikan informasi bahwa hubungan antara keterampilan berpikir kritis dengan penguasaan konsep pada kelas eksperimen memiliki hubungan positif yang ditunjukkan oleh nilai signifikansi yang lebih kecil dari 0.01 . Berdasarkan angka koeefisien korelasi yang ditunjukkan di dalam Tabel 3 di atas bahwa hubungan antara keterampilan berpikir kritis dan penguasaan konsep berada pada kategori kuat. Hubungan yang bersifat positif antar variabel dapat dimaknai bahwa semakin tinggi nilai keterampilan berpikir kritis mahasiswa maka semakin tinggi penguasaan konsepnya.

Besar pengaruh variabel keterampilan berpikir kritis terhadap variabel penguasaan konsep dilakukan penghitungan koofesien determinasi $\left(\mathrm{r}^{2}\right)$, hasilnya diperlihatkan pada Tabel 4.

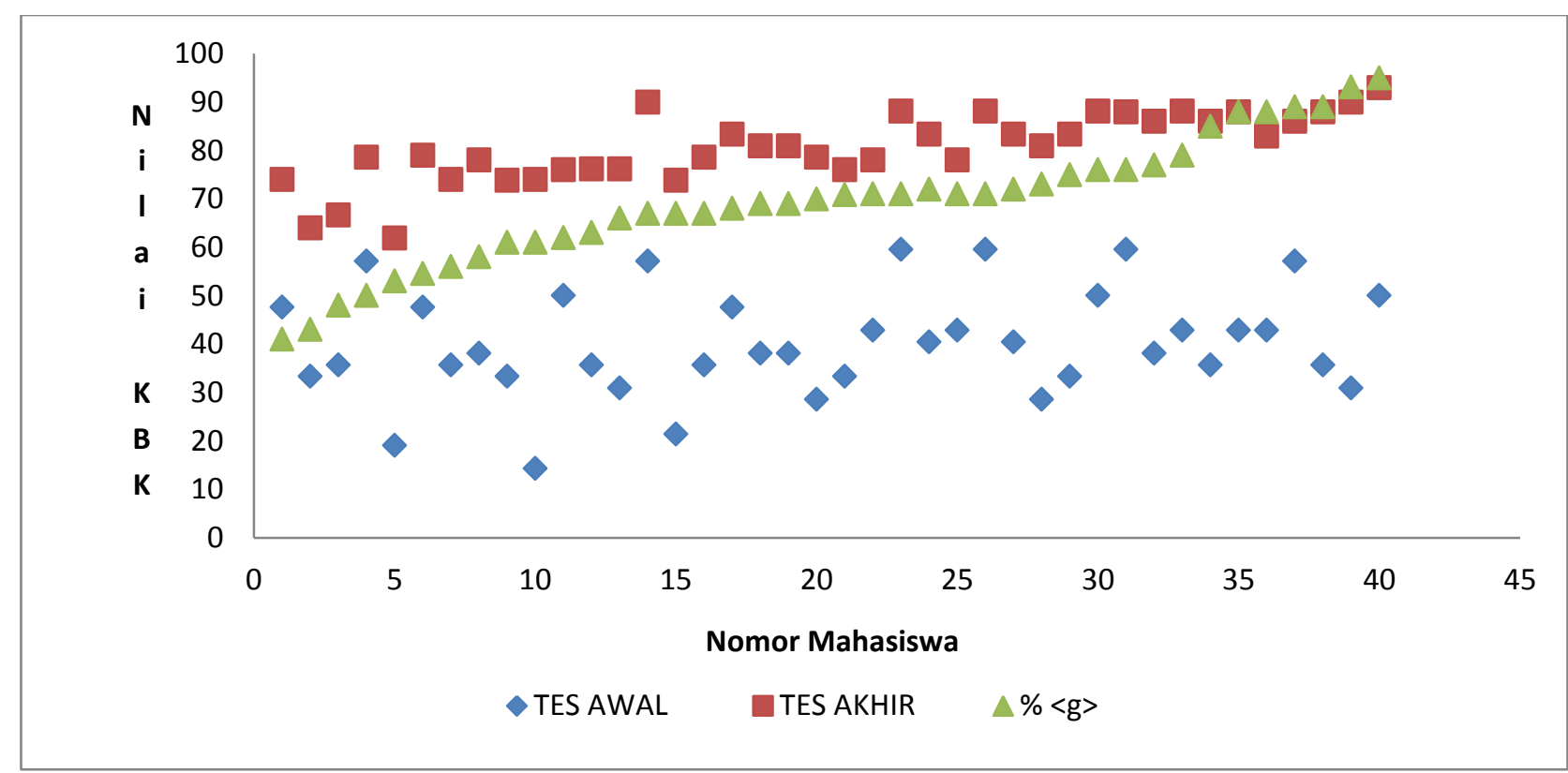

Keterangan: $n=40$ orang

Gambar 3. Sebaran nilai tes awal, tes akhir dan \% n-gain $(<\mathrm{g}\rangle)$ keterampilan berpikir kritis mahasiswa yang menggunakan TBL pada materi zoologi vertebrata

Tabel 3. Hasil Uji Korelasi Pearson two tailed pada kelas eksperimen

\begin{tabular}{ccccccc}
\hline \multirow{2}{*}{ Variabel } & \multicolumn{3}{c}{ KBK } & \multicolumn{2}{c}{ PK } \\
\cline { 2 - 7 } & S & Sig & Makna & r & Sig & Makna \\
\hline KBK & 0.637 & 0.000 & kuat & 0.673 & 0.000 & kuat \\
PK & & & & 1 & \\
\hline
\end{tabular}

Tabel 4. Koofisien Determinasi Antara Variabel Keterampilan Berpikir Kritis Dan Penguasaan Konsep Mahasiswa

\begin{tabular}{cccc}
\hline \multirow{2}{*}{ Variabel hubungan } & \multicolumn{3}{c}{ Kelas Eksperimen } \\
\cline { 2 - 4 } & $\mathbf{R}$ & $\mathbf{r}^{\mathbf{2}}$ & $\mathbf{\%} \mathbf{r}^{\mathbf{2}}$ \\
\hline Keterampilan Berpikir kritis dan Pengusaan Konsep & 0.637 & 0.41 & 41 \\
\hline
\end{tabular}




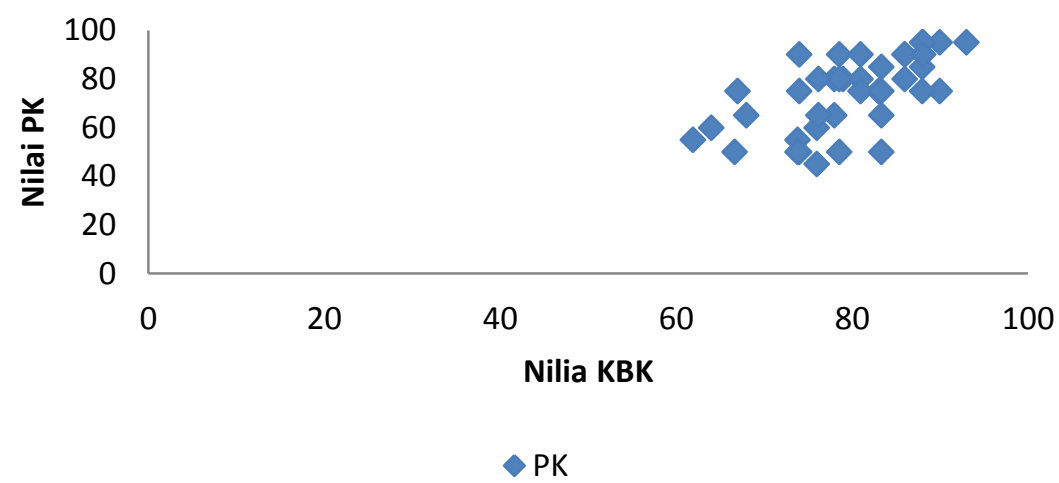

Gambar 4. Sebaran nilai keterampilan beripikir kritis terhadap nilai penguasaan konsep pada kelas yang mengimplentasikan TBL

Tabel 4 memberikan informasi bahwa keterampilan berpikir kritis memberikan kontribusi $41 \%$ terhadap penguasaan konsep, sisanya (59\%) dipengaruhi oleh faktor-faktor yang lain. Dahar (2011) mengemukakan bahwa siswa membangun konsep dalam pikirannya melalui dua cara yaitu penalaran induktif dan deduktif. Kedua kemampuan tersebut merupakan bagian dari indikator berpikir kritis atau merupakan keterampilan dasar berpikir kritis (Ennis et al. 2005), sehingga ada irisan antara berpikir kritis dengan penguasaan konsep. Seorang yang berpikir kritis dia akan berusaha menemukan konsep-konsep dari fenomena tersebut akibatnya dia bisa menguasai konsep, seperti yang ditunjukkan oleh data pada Tabel 4 bahwa terdapat hubungan yang kuat antara berpikir kritis dan pengguasaan konsep. Menurut Johnson dan Siegel (2010) bahwa keterampilan berpikir dapat membantu peserta didik dalam mengkontruksi pengetahuan sehingga menghasilkan penguasaan konsep yang utuh. Selain itu, Kogut (1996) mengemukakan bahwa keterampilan berpikir kritis dapat mencegah miskonsepsi pada mahasiswa sehingga terhindar dari kesalahan dalam menghubungkan konsep baru dan pengetahuan yang telah dimiliki sebelumnya. Menurut Taghva et al (2014). Mahasiswa dengan tingkat berpikir kritisnya tinggi, dia memiliki kemampuan dalam memroses informasi, mengorganisasi, menginferensi, mengeskplorasi dan terbuka terhadap pengalaman baru yang lebih baik dibandingkan dengan mahasiswa yang keterampilan berpikir kritisnya kurang. Akibatnya kinerja akademiknya termasuk penguasaan konsepnya menjadi lebih baik. Demikian juga dengan pendapat Kamaei \& Weisani (2013) yang mengemukakan bahwa mahasiswa dengan tingkat berpikir kritis yang tinggi memiliki kemampuan yang sangat baik untuk menerima dan memproses informasi dan mengaturnya dengan cara yang tepat, memiliki kekuatan penalaran dan deduksi, rasa ingin tahu, toleransi dan keterbukaan pikiran, kekuatan mendeteksi dan menghindari prasangka, mereka dapat lebih memenuhi tugas dan tantangan pendidikan dan karena itu mereka memiliki kinerja akademis yang lebih tinggi daripada mereka yang memiliki tingkat berpikir kritis yang rendah. Paparan di atas menunjukkan bahwa keterampilan berpikir kritis memberikan kontribusi bagi peningkatan penguasan konsep mahasiswa. Demikian juga dalam penelitian ini, seperti yang diungkap pada tabel 3 dan 4 di atas. Untuk lebih jelasnya dapat dilihat dari sebaran nilai keterampilan berpikir kritis dan penguasaan konsep mahasiswa pada Gambar 4.

Gambar 4 dapat dilihat bahwa sebaran nilai pada kelas yang menerapkan strategi TBL, terlihat merata, sehingga dari meratanya sebaran nilai dapat disimpulkan tersebut hubungan antara variabel penelitian bersifat positif.

Hal ini pun sejalan dengan berbagai penelitian yang menunjukkan bahwa terdapat hubungan positif antara keterampilan berpikir kritis dan capaian akademik mahasiswa, di antaranya adalah penelitian Facione (2013) yang melaporkan bahwa skor keterampilan berpikir kritis mahasiswa berkorelasi secara signifikan dengan indeks prestasi mereka. Ghazivakili et al (2014) melaporkan bahwa terdapat hubungan yang positif antara gaya belajar, keterampilan berpikir kritis dan kinerja akademik mahasiswa. Vierra (2014) melaporkan bahwa terdapat keterkaitan yang erat antara keterampilan berpikir kritis dengan capaian akademik. 


\section{PENUTUP}

Berdasarkan hasil penelitian seperti yang dipaparkan di atas bahwa strategi pembelajaran berbasis kelompok (TBL) mampu meningkatkan penguasaan konsep mahasiswa yang lebih baik dibandingkan dengan pembelajaran pada kelas kontrol. Peningkatan penguasaan konsep mahasiswa selain dipengaruhi oleh strategi pembelajaran juga ada kaitannya dengan keterampilan berpikir kritis mereka, yang ditunjukkan oleh adanya hubungan positif antara keterampilan berpikir kritis dengan penguasaan konsep mahasiswa. Berdasarkan penelitian ini, strategi pembelajaran berbasis kelompok (TBL) dapat digunakan sebagai alternatif strategi pembelajaran untuk konsep-konsep yang lainnya.

\section{DAFTAR PUSTAKA}

Bailin S. 2002. Critical Thinking and Science Education. Science \& Education 11:361375 .

Bransford JD, Brown AL, Cocking RR. 2000. How People Learn: Brain, Mind, Experience, and School (Expanded Ed.). Washington, Dc: National Academy Press.

Behling KC, Murphy MM, William JM. McQuade. H.G. and Lopez, O.J. 2016 Team-Based Learning in a Pipeline Course in Medical Microbiology for Under-Represented Student Populations in Medicine Improves Learning of Microbiology Concepts. Journal Of Microbiology \& Biology Education 370379.

Blake B, Pope T. 2008. Developmental Psychology: Incorporating Piaget's and Vygotsky's Theories in classrooms. Journal of cross Disciplinary Perspectives in Education, 1(1):59-67.

Chung EK, Rhee J, YH Oh-Sun . 2009. The Effect of Team-Based Learning in Medical Ethics Education. Medical Teacher 31:1013-1017.

Clair K, Cihara L. 2012. Team-Based Learning in a Statistical Literacy Class. Journal of Statistics Education 20(1).
Cohen J. 1988. Statistical Power Analysis for the Behavioral Sciences (2nd ed.). Hillsdale, NJ: Lawrence Earlbaum Associates

Dahar RW. 2011. Teori-Teori Belajar. Jakarta: Erlangga.

Ennis RH, Millman J, Tomko N.T. 2005. Administration Manual Cornell Critical Thinking Test . The Critical Thinking Co: California.

Facione PA. 2013. Critical Thinking: What it is and Why it Counts. Measured Reason. The California Academic Press, Millbrae CA.

Fink LD. 2004. Beyond Small Groups: Harnessing the Extraordinary Power of Learning Teams. In Michaelsen LK, Knight AB, Fink L (Eds), Team-Based Learning: A Transformative use of Small Groups in College Teaching, 3-26, Stylus Publishing, Sterling, VA, United States.

Ghazivakili Z, Nia NR, Panahi F. Karimi M. Gholsorkhi, H. Ahmadi, Z. 2014. The Role of Critical Thinking Skills and Learning Styles of University Students in their Academic Performance. J. Adv. Med. Educ. Prof. 2(3).

Hake RR. 1998. Interactive-engagement versus traditional methods: A Six-ThousandStudent Survey of Mechanics Test Data for Introductory Physics Courses. American Journal of Physics 66(1).

Hickman CP, Robert LS, Larson A. 2001. Integrated Principal of Zoology. New York: McGrawHill Company.

Hrynchak P, Batty H. 2012 The Educational Theory Basis of Team-Based Learning. Medical Teacher 34:796-801.

Huitt TW, Killins A, Brooks WS. 2014. TeamBased Learning in the Gross Anatomy Laboratory Improves Academic Performance and Students' Attitudes Toward Teamwork. Anat Sci Educ 00:00-00.

Hungerford HR, Volk TL, Ramsey JM. 1990. Science-Technology-Society: Investigating and Evaluating STS Issues and Solution. Illinois: STIPES Publishing Co. 
Janssen HF, Skeen NP, Bell J, Bradshaw W. 2008. Improving Critical Thinking Skills in the Medical Professional with Team-Based Learning. In Michaelsen, L.K. Parmelee, D.X., McMahon, K.K. and Levine, R.E. (editor) Team-Based Learning for Health Professions Education A Guide to Using Small Groups for Improving Learning. Stylus Publishing, LLC, Sterling Virginia.

Jonshon S, Siegel H. 2010. Teaching Thinking Skills. 2nd Edition. Continuum International Publishing Group: New York

Kamaei A, Weisan Mokhtar. 2013. The Relationship Between Achievement Motivation, Critical Thinking and Creative Thinking with Academic Performance. Indian Journal of Fundamental and Applied Life Sciences 3(4):121-127.

Kogut LS. 1996. Critical Thinking in General Chemistry". Journal of Chemical Education. 73(3):218-221.

Lamm MH, Dorneich M, Rover DT. 2014. TeamBased Learning in Engineering Classrooms: Feedback Form and Content Adds Value to the Learning Experience. ASEE North Midwest Section Conference Proceeding.

Lee JS. 2014. The Relationship between Student Engagement and Academic Performance: Is It a Myth or Reality? The Journal of Educational Research, 107:177-185.

Leech NL. Barret, KC and Morgan, GA. 2005. SPSS for Intermediate Statistics: Use and Interpretation $\left(2^{\text {nd }} e d\right)$. New Jersey: Lawrence Erlbaum Associates, Inc.

Lettassy NA. Fugate, SE. Medina, MS. Stroup, J.S. and Britton, M.L. 2008. Using Team-Based Learning in an Endocrine Module Taught Across Two Campuses. American Journal of Pharmaceutical Education 72(5).

Livingston B, Lundy M, Harrington S. 2014. Physical Therapy Students ' Perceptions of Team-Based Learning in Gross Anatomy using the Team-Based Learning Student Assessment Instrument. Journal of Educational Evaluation for Health Professions 10:1-10
Marks HM. 2000. Student Engagement in Instructional Activity: Patterns in the Elementary, Middle, and High School Years. American Educational Research Journal 37:153-184

Michaelsen LK, Sweet M. 2008a. The Essential Elements of Team-Based Learning. New Directions For Teaching And Learning 116.

Michaelsen LK, Sweet M. 2008b. Fundamental Principles and Practices of Team-Based Learning. In Michaelsen, L.K. Parmelee, D.X., McMahon, K.K. and Levine, R.E. (editor) Team-Based Learning for Health Professions Education A Guide to Using Small Groups for Improving Learning. Stylus Publishing, LLC, Sterling Virginia.

Milne I. 2004. Aims and Goals for Science Education. From TKI | NZ Curriculum Marautanga Project | What's happening | Science | Aims and goals for science education. Melalui https://www.google.com/?gws_rd=ssl\#q=Ai ms+and+Goals+for+Science+Education+htt p:\%2F\%2Fwww.tki.org.nzcurriculum\%2Fw hats_happening\%2Findex_e.php

Nieder GL, Parmelee DX, Stolfi A, Patricia D. Hudes, P. 2005. Team-Based Learning in a Medical Gross Anatomy and Embryology Course. Clinical Anatomy 18:56-63.

National Research Council. 1996. National Standard of Science Education. NRC : New York.

Ofstad W, Brunner LJ. 2013. Team-Based Learning in Pharmacy Education American Journal of Pharmaceutical Education 77(4).

Parappilly M, Schmidt L, De Ritte S. 2015. Ready to Learn Physics: A Team-Based Learning Model for First Year University. Eur. J. Phys. 36.

Rezaee R, Mosalanezad L. 2015. The Effect of Case-Based Team Learning on Student' Learning, Self Regulation and Self Direction. Global Journal of Health Science 7(4):295- 306. 
Rutherford FJ, Ahlgren A. 1990. Science for All Americans. Oxford: Oxford University Press.

Sund RB, Trowbridge L. 1973. Teaching Science by Inquiry in The Secondary School. Ohio: Charles E. Merril Publishing Co.

Taghva F, Rezaei N, Ghaderi J, Taghva R. 2014. Studying the Relationship Between Critical Thinking Skills and Students' Educational Achievement (Eghlid Universities As Case Study) international letters of social and humanistic.

Trowbribge LW, Bybee RW. 1990. Becoming a secondary School Science Teacher.
Columbus : Merrill Publishing Co., A Bell \& Howell Information Co.

Vierra RW. 2014. Critical Thinking: Assessing the Relationship with Academic Achievement and Demographic Factors. Dissertation. In Partial Fulfillment of The Requirements for The Degree of Doctor of Education Faculty of The Graduate School of The University of Minnesota.

Wiegant F, Boonstra J, Peeters A, Scager K. 2012. Team-Based Learning in Honors Science Education: The Benefit of Complex Writing Assignments. Journal of the National Collegiate Honors Council 13(2). 